\title{
Erratum to: Abuse potential of methylenedioxymethamphetamine (MDMA) and its derivatives in zebrafish: role of serotonin 5HT2-type receptors
}

\author{
Luisa Ponzoni ${ }^{1,2} \cdot$ Daniela Braida $^{2} \cdot$ Mariaelvina Sala $^{3}$
}

Published online: 26 September 2016

(C) Springer-Verlag Berlin Heidelberg 2016

Erratum to: Psychopharmacology 233(15): 3031-3039

DOI 10.1007/s00213-016-4352-4

The original version of this article contained a mistake in the second author name as well as in the affiliation of authors. Correct presentation is presented here.

The online version of the original article can be found at http://dx.doi. org/10.1007/s00213-016-4352-4

Mariaelvina Sala

mariaelvina.sala@unimi.it

1 Fondazione Umberto Veronesi, Milan, Italy

2 Department of Medical Biotechnology and Translational Medicine (BIOMETRA), Università degli Studi di Milano, Milan, Italy

3 Institute of Neuroscience, Consiglio Nazionale delle Ricerche (CNR), Milan, Italy 